\title{
A New Species of Genus Dryinus (Hymenoptera: Dryinidae) from Korea
}

\author{
Jong-Wook Lee* and Chang-Jun Kim \\ Department of Biology, Yeungnam University, Gyeongsan 712-749, Korea
}

\begin{abstract}
A new species of parasitoid wasp, Dryinus baegamensis n. sp. of the family Dryinidae, is described from Korea. A Key to the Dryinus species of Eastern Palaeartic region, description and photographs of diagnostic characters are provided.
\end{abstract}

Keywords: Dryinus baegamensis n. sp., Dryininae, Dryinidae, Korea

\section{INTRODUCTION}

The Genus Dryinus (Hymenoptera: Dryinidae) is a parasitoid of Auchenorrhyncha (Fulgoromorpha) (Guglielmino and Olmi, 1997, 2006, 2007). It is one of the largest genus within the subfamily Dryininae, with 242 extant species (Olmi, 1999).

The Dryinus Latreille is cosmopolitan, but mainly from the tropical and subtropical regions (Olmi, 2008). 51 Dryinus species have been recorded in Oriental Region, 12 species in the Eastern Palaeartic Region (Olmi, 1984, 2009; Mita, 2009) and only one species, Dryinus koreanus (Moczar) is recognized in Korea so far.

The members of Dryinus are small to moderate sized wasps and distinguished from species belonging to other dryininae genera by the following combination of morphological characters: 1) mandible with four teeth that getting larger from anterior one to posterior, 2) lateral regions of the prothorax not continuous with the mesopleura, and prospectus visible, 3) tibial spurs formula usually 1-1-2, but occasionally 1-1-1 (Olmi, 1984).

In this study, we report one new species, Dryinus baegamensis n. sp. from Korea. A key to the Dryinus species of Eastern Palaeartic region, description and photographs of diagnostic characters are provided.

The terminologies for morphological characters follow Olmi (1984, 1994, 1999) and He and Xu (2002). Photographs are captured with Axiocam MRc5 camera through a stereomicroscope (Stemi SV 11 Apo; Carl Zeiss, Göttingen, Germany), produced with AxioVision40AC software (Carl Zeiss, Göttingen, Germany) and optimized with an $i$-delta imaging system. Materials used in this study have been collected by sweeping.

*To whom correspondence should be addressed

Tel: 82-53-810-2376, Fax: 82-53-811-2376

E-mail: jwlee1@yumail.ac.kr
Abbreviations as follows: TS, Type species. POL, distance between the inner edges of the two lateral ocelli; OL, distance between the inner edges of a lateral ocellus and median ocellus; OOL, distance from the outer edge of a lateral ocellus to the compound eye; OPL, distance from the posterior edge of a lateral ocellus to the occipital carina.

\section{SYSTEMATIC ACCOUNTS}

Order Hymenoptera

Superfamily Chrysidoidea Day, 1977

Family Dryinidae Latreille, 1804

Subfamily Dryininae Kieffer, 1906

Genus Dryinus Latreille, 1804

Dryinus Latreille, 1804: 176. TS: Sphex collaris Linnaeus, 1767.

Campylinyx Westwood, 1835: 52. TS: Campylonyx ampuliciformis Westwood, 1835.

Mesodryinus Kieffer, 1906: 497. TS: Dryinus niger Kieffer, 1904: 352.

Lestodryinus Kieffer, 1911: 108. TS: Sphex cillaris Linnaeus, 1767 (new name for Dryinus Latreille).

Diagnosis. Female: Fully winged; Antennae with no tufts of long hair; Maxillary palps 6 segmented. Labial palps 3 segmented; mandible with four teeth that getting larger from anterior one to posterior; lateral regions of the prothorax not continuous with the mesopleura, and prospectus visible; Notaulices at least partly visible; Enlarged claw as long as, or shorter than fore tibia, much longer than arolium with one subapical tooth (rarely two) and some lamellae; tibial spurs formula usually 1-1-2, but occasionally 1-1-1.

\section{A key to the Dryinus species of Eastern Palaeartic region}

1. Body testaceous, only petiole black 

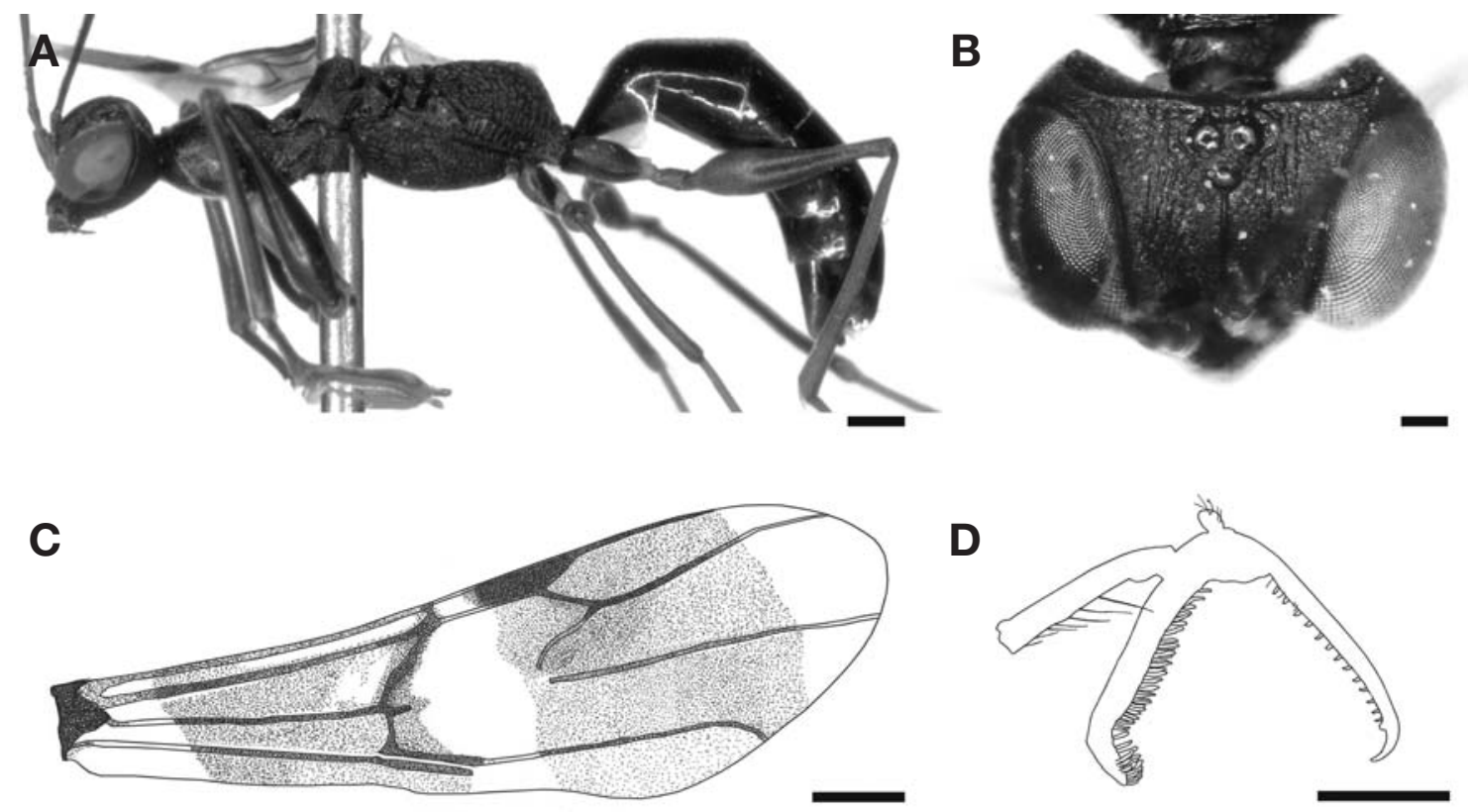

Fig. 1. Dryinus baegamensis n. sp. A, Body in lateral view; B, Head in Dorsal view; C, Forewing; $D$, Chele. Scale bars $=0.5 \mathrm{~mm}(A$, C), $0.2 \mathrm{~mm}(B), 500 \mu \mathrm{m}(\mathrm{D})$.

- Body mostly black

\section{. 3}

2. Notaulices reaching 0.65 length of scutum $\cdots \cdots$ koreanus

- Notaulices reaching 0.5 length of scutum ......... indicus

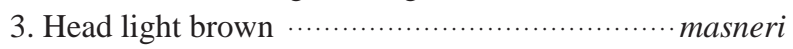

- Head black …........................................... 4

4. Frons strongly reticulated or rugose $\cdots \cdots \ldots \ldots \ldots . . \cdots$ chenae

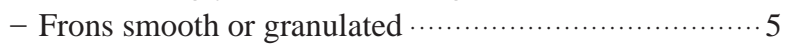

5. Forewing with 2 dark transversal bands …............. 6

- Forewing with 3 dark transversal bands …............. 7

6. Head with POL longer than OL, Enlarged claw with a row of 16 lamellae ................................. sinicus

- Head with OL longer than POL, Enlarged claw with a row of 13 lamellae …............... baegamensis $\mathrm{n} . \mathrm{sp}$.

7. Frons narrower than scutellum …............... bellicus

- Frons broader than scutellum …...................... 8

8. Notaulices incomplete …......................... latus

- Notaulices complete …...............................9

9. Temple distance longer than diameter of anterior ocellus .10

- Temple distance shorter than diameter of anterior ocel-

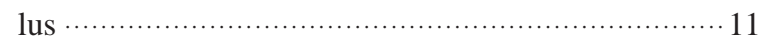

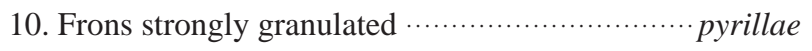

- Frons weakly or not granulated …............ pyrillivorus

11. Antennal segment 3 more than six times as long as

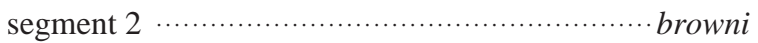

- Antennal segment 3 less than six times as long as segment 2
12. Notaulices complete (posteriorly separated), Metanotum with anterior half reticulate rugose...$\cdots \ldots \ldots \ldots$ expolitus - Notaulices almost complete, Metanotum granulated ...... krombeini

\section{Dryinus baegamensis n. sp.}

Type material. Holotype, 1 우, Korea: Gyeongsangbuk-do, Yeongyang-gun, subi-myeon, Mt. Baegam, 10 July 1999 (J.W. Lee). Paratype, 1 우, same data as holotype. The types are deposited in the Animal systematic laboratory of the Yeungnam University (YNUE).

Description. Female. Fully winged. Body length $8.1 \mathrm{~mm}$. Head and body black. Clypeus black, with anterior margin testaceous. Mandible testaceous, teeth of mandible reddishbrown. Antennae reddish-brown, 1-2 segments testaceous, 7-10 segments yellow. Legs testaceous, with coxae and femora reddish-brown partly black. Dorsal surface of abdomen black and ventral surface redish-brown (partly black). Antennae filiform; antennal segments in following proportions: $9: 6: 41: 19: 14: 13: 8: 8: 8: 9$. Head weakly granulated. Frons and vertex with some tracks of longitudinal keels, covered with short hair, frontal line visible. Occipital carina complete, laterally not reaching the compound eyes, two lateral ocelli with irregular keels joining the occipital carina; POL: 1; OL: 1.5; OOL: 8.5; OPL: 2. Pronotum which is crossed by 2 transversal impressions (anterior impression 
very weakly visible) and covered with short hairs, shining with many longitudinal striate around the disc. Scutum, sutellum and metanotum granulated. Notauli reaching to apical margin. Mesopleura rugose. Metapleura strongly striate. Propodeum shining, dorsal and porsterior surface reticulate rugose, covered with very short hair. Forewing with 2 dark transverse bands; distal part of stigmal vein about 4.0 as long as proximal part. Enlarged claw as in Fig. 1D with a subapical tooth and a row of 13 lamellae. Fifth segments of fore tarsus spatulate with two rows of lamellae in inner margin. Fore and mid tibia with 1 spur; hind tibia with 2 spurs, inner spur longer than outer spur. Abdomen smooth and shiny, with some short hairs.

Male. Unknown.

Distribution. Korea.

Host records. Unknown.

Remarks. Dryinus baegamensis n. sp. can be easily distinguished from Dryinus koreanus which is another known Korean species by the following characteristics: Body length. D. koreanus body length $(3.84 \mathrm{~mm})$, much shorter than Dryinus baegamensis n. sp.

Etymology. The species is named after its collecting site, Mt. Baegam.

\section{ACKNOWLEDGEMENTS}

We thank to Mr. Seung-Ho Oh for preparing figures and useful comments on earlier draft. Also thank Dr. Jong-Chul Jeong for useful comments on this paper. This study was supported by the Korean Institute of Environmental Science and Technology, Ministry of Environment grant (KIEST 052-081-213 072) and the Ministry of Environment of the Korean Government.

\section{REFERENCES}

Day, M.C., 1977. A new genus of Plumariidae from Southern Africa, with notes on Scolebythidae (Hymenoptera: Chrysidoidea). Cimbebasia, 4: 171-177.

Guglielmino, A. and M. Olmi, 1997. A host-parasite catalog of world Dryinidae (Hymenoptera: Chrysidoidea). Contribu- tion on Entomology, International, 2(2): 165-298.

Guglielmino, A. and M. Olmi, 2006. A host-parasite catalog of world Dryinidae (Hymenoptera: Chrysidoidea): first supplement. Zootaxa, 1139: 35-62.

Guglielmino, A. and M. Olmi, 2007. A host-parasite catalog of world Dryinidae (Hymenoptera: Chrysidoidea): second supplement. Boll. Zool. Agr. Bachic (Ser. ii), 39: 121-129.

He, J. and Z. Xu, 2002. Hymenoptera Dryinidae. Fauna Sinica, 29. Science Press, Beijin, p. 464.

Kieffer, J.J., 1904. Description de nouveaux Dryininae et Bethylinae du Musée Civique de Génes. Annali del Museo Civico di storia Naturale di Genova, 41: 351-412.

Kieffer, J.J., 1906. Zwei neue Dryinidae aus Ost-Indien (Hymenoptera). Zeitschrift für Hymenopterologie und Dipterologie, 5: 335-336.

Kieffer, J.J., 1911. Description d'un nouveau dryinide des Indes orientales. Bull. Soc. Hist. nat. Mets, 27: 107-110.

Latreille, P.A., 1804. Nouvelle dictionnaire d'Historie naturelle. Paris, 24: 129-200.

Linnaeus, C., 1767. Systema Naturae per Regna Tria Naturae, Secundum Classes, Ordines, Genera, Species, Cumcaracteribus, Differentiis, Synonymis, Locis, 12th ed. (revised), Holmiae, pp. 533-1327.

Mita, T., 2009. A taxonomic study of the Dryininae (Hymenoptera: Dryinidae) of Japan, with description of a new species of Pseudodryinus. Zootaxa, 2168: 45-56.

Moczar, L., 1983. Dryinids from Korea (Hymenoptera: Dryinidae). Acta Zool. Acad. Sci. Hung, 29: 181-195.

Olmi, M., 1984. A revision of the Dryinidae (Hymenoptera). Memoirs of the American Entomological Institute, 37: 11913.

Olmi, M., 1994. The Dryinidae and Embolemidae (Hymenoptera: Chrysidoidea) of Fennoscandia and Denmark. Fauna Entomologica Scandinavica, 30. Bill, Leiden, p. 100.

Olmi, M., 1999. Hymenoptera Dryinidae-Embolemidae. Fauna d'Italia, 37, Edizioni Calderini, Bologna, p. 425.

Olmi, M., 2008. Order Hymenoptera, family Dryinidae. In: Arthropod Fauna of the U.A.E(Ed., Harten, A. van), 1: 361-371.

Olmi, M., 2009. A contribution to the study of the Palaearctic Dryinidae, including descriptions of two new species from Japan and South Korea (Hymenoptera: Chrysidoidea). Entomologist's Gazette, 60: 127-134.

Westwood, J.O., 1835. Genus Campylonyx. Proc. Zool. Soc. Lond, 3: 52.

Received February 10, 2010 Accepted March 11, 2010 